\title{
Textbook evaluation: A reflection on the New Interchange Series
}

Soleimani, Hajar $\bowtie$

University of Isfahan, Iran (h_soleimani82@yahoo.com)

Dr. Dabbaghi, Azizollah

University of Isfahan, Iran (azzizollahd@hotmail.com)

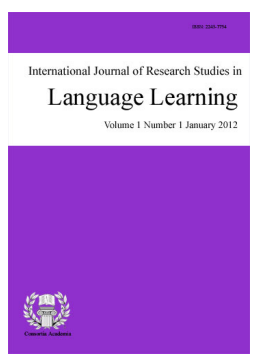

ISSN: 2243-7754 Online ISSN: 2243-7762

OPEN ACCESS

\section{Abstract}

The present study set out to evaluate the efficiency of the New Interchange course books in terms of providing sufficient and comprehensible pragmatic input for Iranian learners of English to fulfill their basic communicative needs based on the content of the books. The study also intended to evaluate the ability of Iranian learners of English in dealing with different speech situations. An oral discourse completion test, developed by the researcher, was administered to 50 students at upper intermediate level of proficiency who already finished the whole New Interchange Series (third edition). Descriptive statistical analyses revealed a high index of standard deviation which indicated a large disparity in pragmatic knowledge of students at the above mentioned level of proficiency. Also Since high achiever's managed to respond to all speech situations using the information provided in their books, it was concluded that the books provided enough pragmatic input for language learners to deal with their basic communicative needs. Findings of the study pedagogically call for using EFL materials which provide sufficient pragmatic input for language learners.

Keywords: textbook evaluation; pragmatic competence; oral discourse completion test; New Interchange Series 


\section{Textbook evaluation: A reflection on the New Interchange Series}

\section{Introduction}

Walking through display of book shops which sell EFL materials in Iran, one can find New Interchange Series dominating the market. There also exist a limited variety of other textbooks and materials for EFL learners but once enrolling language institutes in Iran especially at beginner to upper intermediate levels, it will be realized that New Interchange Series are mostly popular in the language programs of Iranian institutes.

What can explain such popularity in our market? Possible reasons might be that, there might be surveys taken from language learners supporting the efficiency of these course books according to a number of criteria. Another reason for such abundance might be lack of any other appropriate or comprehensive input provider course book to fulfill major communicative and linguistic needs of language learners. Ease of teaching parts of the book according to its clear guidelines or variety of topics provided might be another justification for teachers to prefer these textbooks to other EFL materials. Also an EGP (English for general purposes) course book can be popular if it helps students master linguistic or communicative competence according to their academic purposes or their social communicative needs. Unfortunately, to the researchers' best knowledge, efficiency of The New Interchange Series has not been academically investigated at least in Iran (Sahragard, Rahimi, and Zaremoayedi, 2009). Thus, this study was conducted in an attempt to show that public use of certain materials for learning a language deserves academic investigations to approve or disapprove its efficiency. Academic research on the efficiency of English language teaching materials will help first, language learners to feel more confident that they are within the right path for their learning purposes. Second, it will give credibility to the work of material developers and academically justify the use of those materials.

\section{Background literature}

It is evident that in EFL contexts teachers and textbooks play central roles as resources of the target language and culture. A textbook is a framework which regulates the programs without which classrooms have no face validity to students and learners don't take their learning serious. In situations when shortage of experts in teaching a foreign language is felt, the role of textbooks become pivotal (Williams, 1983). Textbooks portray the role of various people in the target society, the way different people at different levels of society express their intentions through utterances (Sahragard, et al., 2009). Indeed, as Williams believed, any textbook should be used in a wise manner since not all information presented in a textbook suite the requirement of different classrooms in the same way. The textbook is a tool, and the teacher must know not only how to use it, but how useful it can be. Although other aspects of instructional situations, including different teaching approaches, students' preferences or other environmental factors, may affect efficiency of textbooks, the effect of textbooks as instructional materials is more significant as texts have the potential to change the objectives of the situation or affect students' motivation (Riazi \& Mosallanejad, 2010). Therefore, selecting a proper textbook for a class has been one of the most important tasks for teachers. Whether the teacher should have the freedom to select the materials for evaluation and adaptation or not still remains controversial.

To answer whether textbooks can facilitate or inhibit learning, Tomlinson (as cited in Carter \& Nunan 2001, p.67) explored two attitudes. The first one asserted that textbooks are convenient since they give systematicity and help progression and the other attitude contended that textbooks are superficial and reductionist in their coverage and aren't able to meet the diverse and broad needs of learners. According to Hall (1995), there are four principles which comprise basics for material development including 1) the need to communicate; 2) the need for long term goals; 3) the need for authenticity; and 4) the need for student centeredness. Many scholars believe ELT materials should stimulate interaction (e.g. Hidalgo, Hall \& Jacobs, 1995; Tomlinson, as cited in Richards, 2010). 
Jolly and Bolitho (1998, as cited in Richards, 2010, p.84) underpinned the following considerations in developing ELT materials:

$>$ Identification of the needs for developing materials

$>$ Exploration of the needs for developing materials

$>$ Contextualizing materials

$>$ Pedagogical realization of materials

$>\quad$ Production of materials

$>\quad$ Student use of materials

$>$ Evaluation of materials based on agreed objectives

There are situations which necessitate evaluating language learning materials. ELT materials evaluation in general addresses the systematic assessment of the value of materials in relation to their objectives and objectives of learners using them. Evaluation can be pre-used, whilst-use and post-use. Post use evaluation, which is applied in the present study, focuses on what happened as a result of using the materials (Tomlinson, 2011). Tomlinson, in his book "Material development in language teaching", focuses on analysis of materials 'as they are' with the content they propose (p.181). Nevertheless, he stated that, the outcome of using materials in classrooms depends on numerous factors including reinterpretation of materials by both teachers and learners (ibid).

In evaluating ELT materials as Williams (1983) stipulated, we link a view of language and pedagogy to a set of criteria. A general criterion might entail considerations of methodology, needs of learners, teacher and the target community in which the language is taught. The above considerations vary in different cultures and learning contexts. It should be acknowledged that no textbook is perfect and it is the teachers' role to compensate shortcomings of textbooks through use of other materials based on needs analysis of language learners (p.251).

As stipulated in Tomlinson (2011), materials evaluation can be objective, which includes analysis of content of materials; subjective, which includes either exploration of what is required of users (analysis of tasks and what learners are expected to do) or subjective inference on materials. A large body of literature is devoted to evaluating textbooks in different contexts. Many scholars have presented checklists for textbook evaluation including Sheldon (1988), Skierso (1991) and Byrd (2001). The most vital aspect was Byrd's emphasis on the textbook being a good fit for teachers, students, and the curriculum, all of which are important as educators seek to use materials and methods appropriate to their particular context. The following textbook evaluation checklist was offered in Williams (1983):

Any ESL/EFL textbook should:

$>$ Give introductory guidance on the presentation of language items and skills (GENERAL)

$>$ Suggest techniques for teaching pronunciation

$>$ Teach grammar in a meaning oriented way

Distinguish the different purposes and skills involved in the teaching of vocabulary (VOCABULARY)

> Provide guidance on the initial presentation of passages for reading comprehension (READING)

Offer guidelines and devices for composition exercises

$>$ Contain appropriate pictures, diagrams, tables, etc" (Williams, p.253). 
Another measure of textbook effectiveness was conducted by TESOL (2002), which stated that effective textbooks must cover the following considerations:

$>\quad$ They should be up-to-date.

$>\quad$ They should contain relevant content.

$>$ They should consider the linguistic and cultural diversity of students.

$>\quad$ The layout and formatting (including font size) should be appropriate for students.

$>\quad$ Visuals and graphics should be clear and culturally sensitive.

$>$ They should present clear, authentic and appropriate audiovisual materials.

$>\quad$ They should address a variety of learning styles.

$>\quad$ They should be usable with a variety of grouping strategies.

$>$ They should contain exercises in which learners share previous experience with prior knowledge of the content.

Recently, improvements among ESL/EFL readers allow students to read more authentic language, read for comprehension, and think critically about reading (e.g., Richards, \& Lesley, 2000).

In Iran also, though limited, a number of researchers have focused on the issue of textbook evaluation. Sahragard et al. (2009), in their article, studied four raters' (with 4-10 years teaching experience) detailed evaluation of The New Interchange Series. Findings of their study indicated that Interchange was not completely along with the objectives intended for it. It didn't use learners or even the teachers as a source for its content. More importantly, task were designed in such a way which made learners just respond to teachers initiative and didn't let learners initiate the tasks. On the other hand, they reported that, Interchange Series focused mainly on pair works and meaning. Analyzing the frequency and percentage of turn takings they found that in $81.34 \%$ of situations, learners were expected to respond to the tasks. Initiation received the next greatest percentage in Interchange textbooks with $13.99 \%$ and the percentage of tasks which didn't require learners either to initiate or respond was $5.05 \%$.

Ansari and Babaii (as cited in Riasati \& Zare, 2010), evaluated a number of textbooks available in Iran market and provided a list of characteristics of appropriate textbooks. As presented in Ansari and Babai, a good EFL/ESL textbook replies on 1) a theory about nature of language; 2) the nature of learning and how the theory can be applied in use; 3 ) an objective for the whole course book and for individual units; 4) teachers' satisfaction with the guide books of the syllabus; and 5) learners' satisfaction with clear instructions for exercises. Jahangard (2007) evaluated high school EFL textbooks in his study. As he concluded, concerning tasks and topics, the textbooks were quite interesting and useful; however, the major pitfall of the textbooks under his study lacked sufficient context for learners to comprehend the new vocabulary provided to them. Another major weak point of high school text books was that the listening skill was completely ignored in those textbooks.

Among their assertions regarding the success of the books as the world's most successful English Series, authors of the New Interchange Series (Richards et al, 1990) believe that the underlying philosophy of the course books is best learned when used for meaningful communication. According to Sahragard et al., (2009), since the publication of the Interchange (3rd edition) in 2006, there has been no research to show to what degree such claims could be valid. Although abundant in Iran market, and so popular among language institutes, effectiveness of the New Interchange Series have only been investigated from the view point of language teachers (e.g. Sahragard et al., 2009; Riasati \& Zare, 2010). Interchange Third edition is a four-book series for adult and young-adult learners of English from the beginning to the high-intermediate level. The Teacher's 
Edition features complete teaching instructions, learning objectives, optional activities, teaching tips, listening scripts, language summaries, and student book and workbook answer keys.

The present study tried to contribute to the growing body of the literature on textbook evaluation through investigating the efficiency of the New Interchange Series in providing sufficient pragmatic input to learners. This study is basically subjective since it isn't analysis of materials but evaluation of the effect of materials on EFL learners. For this purpose, students' responses to a variety of oral discourse completion tasks, developed by the researcher, were evaluated. The evaluation was based on the input presented to learners which was listed in the table of contents of the students' course books. The present study tried to address the following questions:

1. Can participants who already passed the whole New Interchange Series for at least 8 continuous terms realize and respond to a variety of speech situations which will be provided to them based on the content of their course books?

2. Have the New Interchange course books been efficient enough in providing required pragmatic input for Iranian learners of English to do things with words and to fulfill their basic communicative needs (those that are addressed in their course books, based on the table of contents of the New Interchange books).

The reason for selecting the New Interchange Series in this study was that first, they are quite popular among language institutes in Iran and second, although a variety of topics are presented via these course books, it seems that a large number of students who pass the whole series for about 8 continuous terms can't communicate their basic intentions. Therefore, this study was planned to see in practice, whether there is sufficient focus on communicative skills of language learners in the aforementioned course books or not.

\section{Method}

\subsection{Participants}

The population of this study consisted of male and female students from a number of Language institutes of Iran in the last semester of summer season, year 2011 at high intermediate level of language proficiency. Before homogenization, participants were about 80 students (25 Males and 55 females) whose ages ranged from 16 to 24. Due to the limited number of students in intact classes the researcher selected the participants from 6 different language institutes. For the purpose of subject selection an Oxford Placement Test (OPT) was administered to the participants and homogenized them in terms of their linguistic competence. Having calculated the mean, to find the homogenized group, all those who scored one standard deviation higher and lower than the mean participated in the study. Let's mention that homogenization and other considerations of validity and reliability caused the researcher to lose 30 participants which will be discussed in the section 4 of this study. Table 1 shows the schematic presentation of participants.

\section{Table 1}

Distribution of the population of the study

\begin{tabular}{lccc}
\multicolumn{1}{c}{ Gender } & Age & No. & The courses they passed \\
\hline Male & $18-24$ & 22 & The whole New Interchange Series (Third Edition) \\
Female & $16-24$ & 28 & The whole New Interchange Series (Third Edition) \\
\hline
\end{tabular}

\subsection{Materials}

An Oxford Placement Test (OPT) for homogenization and subject selection along with an oral discourse completion test, developed by the researcher, constituted materials of this study. According to participants' acknowledgement, their pragmatic knowledge of English was basically limited to their course book which was 
Soleimani, H. \& Dabbaghi, A.

The New Interchange Series (third edition).

\subsection{Procedures}

The process of homogenization was performed using the grammar part of Oxford Placement Test (OPT). Figure1 shows the result of the OPT test (from which the grammar part was used only). As the histogram illustrates performance of participants on the OPT test which was administered for the purpose of homogenization has the mean score of 45.56 and a standard deviation of 11.6. The large value of SD indicates the disparity of test scores before assigning the homogenized group.

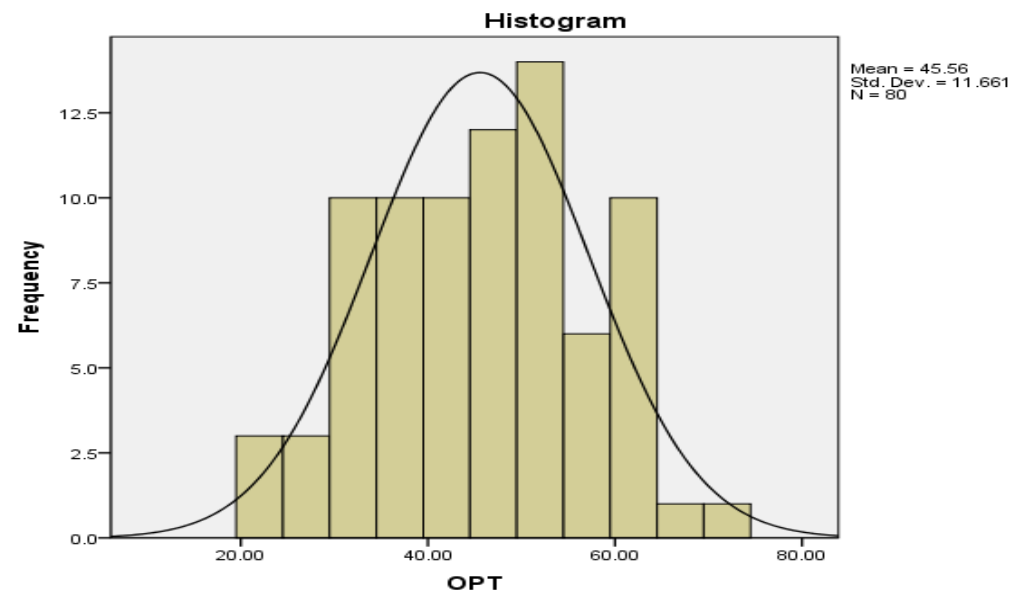

Figure1. Performance of 80 students on the Oxford Placement Test

The implicit point to consider here is that homogenization process led to elimination of 30 participants of this study which is a relatively large figure. Also despite participants were all selected from a close age groups of students who were all at the last week of the last course to finish the whole New Interchange Series, the large value of standard deviation (Fig.1 SD=11.6) shows a large disparity of test scores which reflects their knowledge of English. This might imply that language institutes act quite subjective in determining the proficiency level of language learners. It could also be inferred that the final or placement tests of language institutes which are the passage to the next levels of proficiency are not reliable or valid enough to be an indicator of students' level of proficiency.

Research data were gleaned through an oral discourse completion test (ODCT). The ODCT was composed of 14 speech situations based on the speech act content of students' course book. Participants were asked to assume themselves in those situations and for each speech event they had to answer a question. Examinees feedback showed that instructions were clear to them. The list of speech situations is presented in the appendix C. The participants' speech was recorded via a simple recorder for further analysis, scoring and for estimates of scorer reliability. The assumed situations were selected from among conversations of the New Interchange Series (Third Edition); the acceptable answers were also elicited from the content of the same textbooks. To exemplify the case, one of the situations was as follows:

Situation: Imagine I invite you for my birthday party, but your answer is No. say and give some reasons.

The students were expected to reject the invitation in a formal polite way; for example "I'd love to but..."

It took approximately 10-15 minutes for each participant to finish the ODCT. The scoring was basically subjective, because there is more than one correct way of responding to each speech situation, and also responses may vary due to students' grammatical and pronunciation errors which can't be scored discretely. Thus inter-rater scoring procedure was administered. Depending on the degree of correctness of their replies, based on the scorer 
judgments, examinees scored from 0 to 4 for responding to each speech situation. Before conducting the test, the oral discourse completion test was piloted to a population of 25 students in order to ensure the reliability and feasibility of the composed test.

\subsection{Estimates of validity}

To ensure the content validity of the test (internal validity) using the guidelines of Nunan and Bailey (2009), it was asked from 3 other instructors of New Interchange Series to judge whether the tests had content validity. Apart from experts' judgments, a table of specification was prepared to confirm inclusion of all functional notional content of the course books in the test. The table of specification showed the relationship between the test and what had been presented to students before the test. And finally, the data collection procedure was considered to remain constant across different administrations of the test to different intact classes.

\subsection{Estimates of reliability}

Tests of oral productions cannot be scored as objective as multiple choice items. Thus validity and reliability of the test cannot be clearly estimated. However it was tried to maintain the reliability of Oral discourse completion test as much as possible. Calculating the reliability of the pilot test through Cronbach Alpha the index of $\mathrm{r}=0.78, p<0.01$ indicated a reasonable tie among test items. After achieving scores from the oral discourse completion test, the researcher built scorer reliability by asking another rater to score the same test based on a pre-specified scoring framework (Appendix C). Simple grammatical errors were ignored to the extent that they didn't block comprehension. Pronunciation errors also weren't counted in case examinees' speeches were understandable. Examinees' wrong choice of vocabulary items, long pauses or hesitations and also their failure in realization of the style (when they were direct in their requests or refusals in situations that they were expected to use formal English) affected their test scores negatively. The inter rater reliability can be estimated by examining how much the rater's scores correlate with each other (Yamashita, 1996). Calculating the index of inter rater reliability using Pearson Product Moment Correlation $r=0.89, p<0.01$ indicated that the scores of the two rater were highly correlated and proved the scores to be reliable. The reliability index of test scores after administering the test to the final population was $\mathrm{r}=0.81, p<0.01$ using Cronbach alpha. This was quite reasonable for reliability of the test.

\section{Data analysis and results}

The raw data collected for this study were statistically analyzed using SPSS.

\subsection{Results of the ODCT}

The descriptive statistic of the oral discourse completion test is presented in table 2. As table shows, performance of participants on the test has mean value of 37.6 showing that $46 \%$ of participants scored above the mean and the other $64 \%$ scored below the mean. Scores range from 22-55 with a high index of standard deviation $(\mathrm{SD}=10.6)$ which implies large disparity between pragmatic competence of language learners.

\section{Table2}

Statistics of students' performance on the ODCT

\begin{tabular}{cccccccccc}
\hline $\mathrm{N}$ & Min & Max & Mean & SD & Var. & \multicolumn{2}{c}{ Skewness } & \multicolumn{2}{c}{ Kurtosis } \\
\hline 50 & 22 & 55 & 37.68 & 10.628 & 112.9 & .195 & .337 & -1.229 & .662 \\
\hline
\end{tabular}

The positive value of skewness indicates that scores are clustered to the left at low values, and the negative kurtosis value implies that the distribution of scores is relatively flat (there are too many scores in the extremes. To get a clear vision of distribution of scores a histogram is presented (figure 2). According to Figure 2 distribution of test scores is quite erratic and not a clear clustering of scores can be observed. This indicates 
Soleimani, H. \& Dabbaghi, A.

disparity of tests score which implies disparity of pragmatic knowledge of Iranian learners of English.

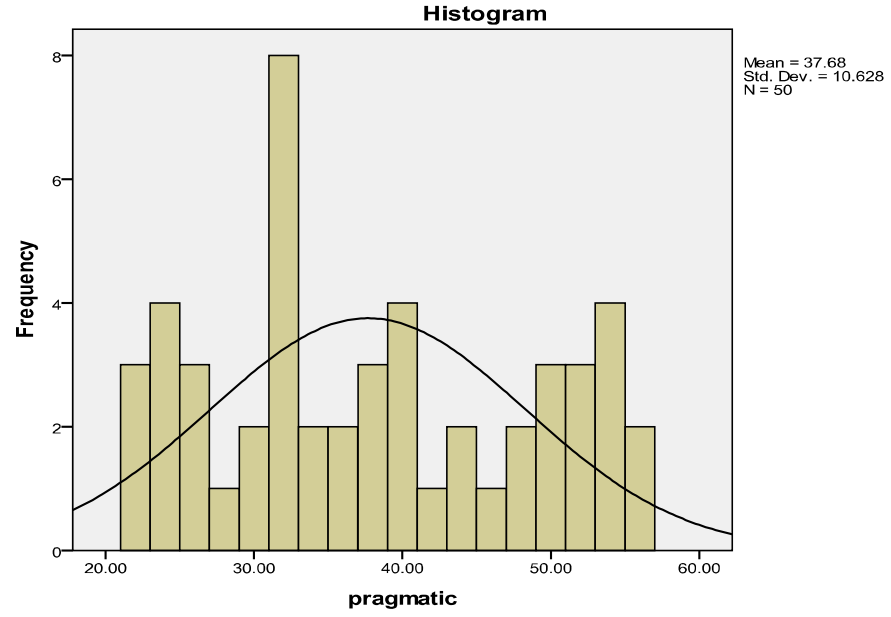

Figure2. Performance of students on the ODCT

\subsection{Peripheral finding}

During the process of data collection and analysis, the researcher came across an interesting finding. When separating the scores acquired from males and females one could easily notice that, in general, male participants scored better on ODCT than ATLC while in females the situation was reverse.

\section{Discussion}

To recall, the focus of this paper was to evaluate efficiency of the New Interchange Course books via evaluation of pragmatic competence of language learners who studied them and to see whether the aforementioned series managed to provide sufficient pragmatic input for Iranian learners of English. Regarding the first question, the findings of this study proved that Iranian learners of English managed to respond to a variety of speech situations which were taken from their course books with a mean score of 37.6 and there was a considerable disparity among performance of participants on the ODCT due to the high index of standard deviation ( $\mathrm{SD}=10.6$ ). As stated in Bardovi-Harlig et al. (1996), "Speakers who do not use pragmatically appropriate language run the risk of appearing uncooperative at the least, or, more seriously, rude or insulting. This is particularly true of advanced learners whose high linguistic proficiency leads other speakers to expect concomitantly high pragmatic competence (p.324)".

The second and the last research question concerned whether the New Interchange Series managed to provide sufficient pragmatic input for Iranian learners of English as the subjects of this study. To answer this question, due to the fact that all of the correct responses of more proficient participants were those which they selected from the New Interchange Series only, and considering the overall analysis of the textbook by the researcher during construction of test items, it can be inferred that the New Interchange Series provides sufficient input for language learners who aim to communicate their basic need of requesting/accepting, requesting/refusing expressing attitudes, and affirming. They achieved such a goal through providing variety of scenarios of different speech situations through audio conversations and video episodes.

\section{Conclusion and implications}

To restate the purpose of the present study was to evaluate the efficiency of the New Interchange Series as EFL materials for Iranian learners of English by examining communicative ability and pragmatic competence of those who spend 8 continuous terms learning English through these course books. The main reason for performing such a research was that so little has been done in evaluating the efficiency of textbooks and EFL 
materials among language institutes and high schools of Iran, especially in terms of fulfilling learners' communicative needs or as Austin (1962) put, in terms of helping Iranian learners of English "do things with words".

Findings of this study are theoretically in line with Hyme's (1972) exploration of communicative competence which includes communicative competence is an essential part of language competence (Leung, 2005). The findings of this paper were also partially in line with those of Sahragard et al. (2009). They made an in-depth evaluation of the Interchange Series and found that the aforementioned textbooks didn't conform to their predefined objectives. Based on their study, Supra sentential was ignored for both the expected output and input of the learners. They also found that learners didn't initiate the task in classrooms teaching the New Interchange series. The only finding conforming to the findings of this study was that Interchange Series focused on pair works and meaning; that the book encouraged students to use the language and more often required them to

The researcher believes that the findings of the present study will hopefully shed light to find an appropriate measure for evaluating text books based on appropriate pragmatic input which they provide to language learners in foreign contexts. Findings of this study might also help New Interchange authors estimate success of their course books in providing learners of variety of cultures, including Iranian learners of English, with sufficient pragmatic input to deal with different communication purposes. The principal problem with the present study might be that it made rather general, impressionistic judgment on the New Interchange Series rather than in-depth examining of what the aforementioned materials contain.

\subsection{Suggestions for further research}

The present study simply described the pragmatic effectiveness of the New Interchange Series through a single test. This study can be expanded comparing the linguistic and pragmatic competence of those language learners who pass the New Interchange Series as their input provider resource. Controlling other factors such as sex, age, or teachers who follow teacher's guide instructions of the aforementioned series can help researchers find out whether there is correlation between pragmatic and linguistic competence of those language learners who pass the whole Series as their course book.

\section{References:}

Austin, J. L. (1962). How to do things with words. Cambridge, MA: Harvard University Press.

Bardovi-Harlig, K. (1996). Pragmatics and language teaching: Bringing pragmatics and pedagogy together. In L. F. Bouton (Ed.), Pragmatics and language learning (Vol. 7, pp. 21-39). University of Illinois, Urbana-Champaign.

Byrd, P. (2001). Textbooks: Evaluation and selection and analysis for implementation. In M. Celce-Murcia, (Ed.), Teaching English as a second or foreign language (3rd ed., pp. 415-428). Boston: Heinle \& Heinle.

Carter, R., \& Nunan, D. (2001). Teaching English to speakers of other languages. Cambridge: Cambridge University Press. < http://dx.doi.org/10.1017/CBO9780511667206>

Hall, D. (1995). In A. C. Hidalgo, D. Hall, \& G. M. Jacobs (Eds.). Getting started: Materials writers on materials writing (pp.8-24). Singapore: SEAMEO Language Center.

Hidalgo, A. C., Hall, D., \& Jacobs, G. M. (1995). Getting started: Materials writers on materials writing. Singapore: SEAMEO Language Center.

Hymes, D. (1972). On communicative competence. In J. B. Pride and Y. J. Holmes (Eds.), Sociolinguistics (pp. 269-293). Hamondsworth: Penguin Books.

Jahangard, A. (2007). The evaluation of the EFL materials taught at Iranian public high schools. Retrieved from http://www3.telus.net/linguisticsissues/bymonth.html

Jolly, D., \& Bolitho, R. (1998). A framework for materials writing. In B. Tomlinson (Ed.). Materials development for language teaching (pp. 90-115). Cambridge: Cambridge University Press. 
Soleimani, H. \& Dabbaghi, A.

Leung, C. (2005). Convivial Communication: Recontextualizing communicative competence. International Journal of Applied Linguistics, 15(2), 119-143. < http://dx.doi.org/10.1111/j.1473-4192.2005.00084.x>

Nunan, D., \& Bailey, K. M. (2009). Exploring second language Classroom research: A comprehensive guide. Boston, MA: Heinle.

Pallant, J. (2007). SPSS survival manual: A step by step guide to data analysis using SPSS. McGraw Hill: Open University Press.

Riazi, A. M., \& Mosallanejad, N. (2010). Evaluation of learning objectives in Iranian high-school and pre-university English textbooks using Bloom's taxonomy. TESL EJ, 13(4), 1-16.

Riasati, M. J., \& Zare, P. (2010). Textbook evaluation: EFL teachers' perspective on New Interchange. Studies in Literature and Language, 1(8), 54-60.

Richards, J. C. (2010). English language teaching materials. Cambridge: Cambridge University Press.

Richards, J. C., \& Lesley, T. (2000). New interchange: English for international communication. Cambridge: Cambridge University Press.

Richards, J., Hull, J., \& Proctor, S. (1990). Interchange, English for international communication. Student book. Cambridge: Cambridge University Press.

Sahragard, R., Rahimi, A., \& Zaremoayedi, I. (2009). An in-depth evaluation of Interchange Series (3rd ed.). Porta Linguarum, 12, 37-54.

Sheldon, L. (1988). Evaluating ELT textbooks and materials. ELT Journal, 42(2), 237-246. $<$ http://dx.doi.org/10.1093/elt/42.4.237>

Skierso, A. (1991). Textbook selection and evaluation. In Celce-Murcia, M. (Ed.), Teaching English as a second or foreign language (2nd ed., pp. 432-453). New York: Newbury House/HarperCollins.

Tomlinson, B. (2011). Materials development for language teaching. Cambridge: Cambridge University Press.

Williams, D. (1983). Developing criteria for textbook evaluation. ELT Journal, 37(3), 251-255. $<$ http://dx.doi.org/10.1093/elt/37.3.251>

Yamashita, S. O. (1996). Six measures of JSL pragmatics (Tec. Rep. No.14). Honolulu: University of Hawaii, Second Language Teaching \& Curriculum Center.

\section{Appendix A}

\section{Oxford Placement Test}

\section{Grammar Test Part I}

Look at these examples. The correct answer is ticked.

A In warm climates people like likes are liking sitting outside in the sun.

B If it is very hot, they sit at in under the shade.

Now the test will begin. Tick the correct answers.

1. Water be freezing is freezing freezes at a temperature of $0^{\circ} \mathrm{C}$.

2. In some countries there is is it is dark all the time in winter.

3. In hot countries people wear light clothes for keeping to keep for to keep cool.

4. In Madeira they have the good good a good weather almost all year.

5. Most Mediterranean countries are more warm the more warm warmer in October than in April

6. Parts of Australia don thave the some any rain for long periods.

7. In the Arctic and Antarctic it is there is it has a lot of snow.

8. Climate is very important in most of most the most peoples' lives. 
9. Even now there is little few less we can do to control the weather.

10. In the future we'll need we are needing we can need to get a lot of power from the sun and the wind.

11. Pele is still perhaps most the most the more famous footballer in the world.

12. He had been is was born in 1940 .

13. His mother not want wasn't wanting didn't want him to be a footballer.

14. But he used ought has used to watch his father play.

15. His father made him to made him would make him to practice every day.

16. He learned to use or his left foot or and his left foot and both his left foot and his right.

17. He got the name Pele when he had only ten years was only ten was only ten years.

18. By 1956 he has joined joined had joined Santos and had scored in his first game.

19. In 1957 he has been picked was picked was picking for the Brazilian national team.

20. The World Cup Finals were in 1958 and Pele was looking forward to play to playing to be playing.

21. But he hurt this the his knee in a game in Brazil.

22. He thought he isn't going to couldn't wasn't going to be able to play in the finals in Sweden.

23. If he hadn't been weren't wouldn't be so important to the team, he would have been left behind.

24. But he was a such such a so brilliant player, they took him anyway.

25. And even though even so in spite of he was injured he helped Brazil to win the final.

26. The history of the World Cup is quite a quite quite short one.

27. Football has been is being was played for

28. above over more that a hundred years, but the first World Cup

29. competition did not be was not was not being held until

30. Uruguay could win were winning had won the Olympic football

31. final in 1924 and 1928 and wanted be being to be World Champions for the third time.

32. Four teams entered from Europe, but with a little few little success

33. It was the first time which that when professional teams

34. are playing would play had played for a world title.

35. It wasn't until four years later more further that a

36. European team succeeded to win in winning at winning

37. for the a its first time. The 1934 World Cup was

38. again won by a the one home team,

39. what this which has been the case several times since

40. then. The 1934 final was among between against two

41. European teams, Czechoslovakia and Italy, which that who won,

42. Went on to win winning to have won the 1938 final. Winning

43. successive finals is something that is not was not has not been achieved

44. again until Brazil did these them it in 1958 and 1962. If Brazil

45. would have won would win had won in 1966 then the 
Soleimani, H. \& Dabbaghi, A.

46. authorities would have needed to have let make the original World Cup replaced.

47. But England stopped the Brazilians to get getting get a third successive win. An England player,

48. Geoff Hurst, scored three goals in the final and won it almost by his own on himself by himself

49. 1966 proved being as being to be the last year that England

50. would will did even qualify for the finals till 1982, though they got in as winners in 1970.

\section{Grammar Test Part 2}

51. Many persons people peoples nowadays believe that everyone should learn to use computers.

52. The majority of children in the UK have has are having access to a micro-computer.

53. There are more computers per head in England than anywhere else somewhere else anywhere other in the world.

54. Learning a computer language is not the same as like than learning a real language.

55. Most people start off with 'Basic', who what which is the easiest to learn.

56. Children seem to find computers to easy, but many adults aren't used to work the work working with micro technology.

57. There aren't no any some easy ways of learning to program a computer.

58. The only way to become really proficient is to practice a lot on your own by your own on yourself.

59. You can pick up the basics quite quickly if you want to would are willing to make an effort.

60. Most adults feel it would be easier if only they would have started would start had started computer studies earlier.

61. Some people would just rather prefer better not have anything to do with computers at all.

62. A lot have resigned themselves to never even know known knowing how a computer works.

63. Micro technology is moving so fast that hardly anybody nobody no one can keep up with it all.

64. It's no use in trying to try trying to learn about computers just by reading books.

65. Everyone has difficulty in learning difficulties to learn it difficult to learn if they can't get 'hands-on' experience.

\section{Below is a letter written to the 'advice' column of a daily newspaper. Tick the correct answers.}

Dear Marge,

66. I am writing I will write I should write to you because

67. I am not knowing don't know know not what to do. I'm twenty-six and a teacher at a primary school in Norwich where

68. I'm working I've worked I work for the last five years. When

69. I was have been had been there for a couple of years, one of the older members of staff

70. would leave left had been leaving and a new teacher

71. would be became was appointed to work in the same department as me.

72. We worked have worked should work together with the same classes during her first year and had the

73. opportunity for building possibilities to build chance to build up a good professional relationship. 
74. Then, about eighteen months after she has arrived to have arrived arriving in Norwich,

75. she decided to buy her own herself her a house.

76. She was tired of to live live living in rented accommodation and wanted a place

77. by her own of her own of herself. At about the same time,

78. I was given have been given gave notice by the landlord of the flat

79. what I was living that I had lived I was living in and

80. she asked me if I liked had liked would like to live with her.

81. She said told explained me that by the time

82. would pay would have paid had paid the mortgage

83. and the bills it there they wouldn't be

84. a lot many few left to live on. She suggested

85. us to we should we may share the house and share the costs.

86. It seemed like a good idea, so after we'd agreed we could agree we agreed with all the details

87. what that who needed to be sorted out, we moved into the new house together.

88. At the end of this month we have lived we have been living we'll have been living together for a year and a half.

89. It's the first time Ilive I'm living I've lived with anybody before,

90. but I should guess I might have guessed I'd have guessed what would happen. I've fallen in love with her and now she's been offered another job 200 miles away and is going to move. I don't know what to

Do. Please give me some advice.

Yours in shy desperation,

Steve

Look at the following examples of question tags in English. The correct form of the tag is ticked.
A He's getting the 9.15 train, isn't he hasn't he wasn't he?
B She works in a library, isn't she doesn't she doesn't he?
C Tom didn't tell you, hasn't he didn't he did he?
D Someone's forgotten to switch off the gas, didn't one didn't they haven't they?

Now tick the correct question tag in the following 10 items:

91. Steve's off to China, has he hasn't he isn't he?

92. It'll be a year before we see him again, won't it won't we shan't it?

93. I believe he's given up smoking, isn't he don't I hasn't he?

94. I'm next on the list to go out there, am not I are I aren't I?

95. No doubt you'd rather he didn't stay abroad too long, shouldn't you wouldn't you hadn'tyou?

96. He's rarely been away for this long before, is he hasn't he has he? 
Soleimani, H. \& Dabbaghi, A.

97. So you think he'll be back before November, shall he will he do you?

98. Nobody's disagreed with the latest proposals, did he has he have they?

99. We'd better not delay reading this any longer, should we did we had we

100.Now's hardly the time to tell me you didn't need a test at all, did you is it isn't it?

\section{Appendix B}

Oral Discourse Completion Test (developed by the researcher)

Instruction: Please listen to the situations provided to you. I want you to put yourself in those situations and answer my questions.

Situation 1: Imagine I am meeting your new friend for the first time. Introduce us to each other.

Situation 2: Imagine I want to buy a pair of shoes for you. One is blue and one is white. Select a color and say it in a sentence.

Situation 3: Imagine you have tickets for a movie tonight (for Example Ekhrajiha). Invite me to come with you.

Situation 4: Imagine I invite you for my birthday party, but your answer is No. say and give some reasons.

Situation 5: Imagine I invite you for a dinner party with your classmates. Say OK and ask for more information.

Situation 6: Imagine I hit your leg when I pass by and I say “ Oh, I'm sorry”. What would you say in reply?

Situation 7: Imagine I'm looking for an address, for example XXX. Help me find it.

Question 8: Describe your home for me.

Situation 9: Imagine you want to buy a house from me. Ask for information about the house.

Situation 10: Imagine I have toothache. Give me some advice or suggestions.

Situation 11: Imagine I'm a waitress at a restaurant. Order your meal.

Situation 12: Imagine you are a waiter or waitress at a restaurant or coffee shop and I'm your customer. Take my order.

Situation 13: Compare Isfahan and Tehran.

Situation 14: Imagine it is cold inside. Ask me to close the window in a polite way.

\section{Appendix C}

Rating framework for ODCT: Very inappropriate 1-2-3-4 Completely appropriate

\begin{tabular}{|l|l|l|l|l|}
\hline Linguistic appropriateness & 1 & 2 & 3 & 4 \\
\hline Amount of speech & 1 & 2 & 3 & 4 \\
\hline Formality & 1 & 2 & 3 & 4 \\
\hline Directness & 1 & 2 & 3 & 4 \\
\hline Politeness & 1 & 2 & 3 & 4 \\
\hline
\end{tabular}

